\title{
Suicide by pesticide ingestion in Nepal and the impact of pesticide regulation
}

\author{
Leah Utyasheva', Dilli Sharma', Rakesh Ghimire², Ayanthi Karunarathne', Gael Robertson ${ }^{1}$ and
}

Michael Eddleston ${ }^{1,3^{*}}$

\begin{abstract}
Background: Nepal recorded 5754 suicides in 2018-19 - a high number for a relatively small country. Over 24\% of these suicides were by poisoning, most by ingestion of highly concentrated agricultural pesticides. Nepal has actively regulated pesticides to reduce their health impacts since 2001. We aimed to analyse Nepal's history of pesticide regulation, pesticides responsible for poisonings, and relate them to national suicide rates.

Methods: Information on pesticide regulation was collected from the Plant Quarantine and Pesticide Management Centre of the Ministry of Agriculture and Livestock Development. National data on suicides from 1980 to 2019 were obtained from the National Statistical Bureau and Nepal Police. Data on the pesticides responsible for self-poisoning and pesticide suicides over time were obtained from a systematic literature review.

Results: As of June 2020, 171 pesticides were registered for use in Nepal, of which one was extremely hazardous (WHO Class la), one other highly hazardous (WHO Class lb), and 71 moderately hazardous (WHO Class II). Twentyfour pesticides have been banned since 2001, with eight (including five WHO Class I compounds) banned in 2019. Although the suicide rate has increased more than twelve-fold since 1980, particularly for hanging (15-fold increase from 1980 to 2018), fatal pesticide self-poisoning has increased by 13-fold. Methyl-parathion is reported to be the key pesticide responsible for pesticide self-poisoning in Nepal, despite being banned in 2006.

Conclusion: The full effect of the recent pesticide policy reform in Nepal remains to be seen. Our analysis shows a continuing increase in suicide numbers, despite bans of the most important pesticide in 2006. This may indicate smuggling across the border and the use of the brand name (Metacid) for pesticides in general making it difficult to identify the responsible pesticide. More information is required from forensic toxicology labs that identify the individual compounds found. The effect of recent bans of common suicide pesticides needs to be monitored over the coming years. Evidence from other Asian countries suggests that HHPs bans will lead to a marked reduction in suicides, as well as fewer cases of occupational poisoning.
\end{abstract}

Keywords: Nepal, Suicide, Poisoning, Pesticides, Means restriction

\footnotetext{
* Correspondence: m.eddleston@ed.ac.uk

${ }^{1}$ Centre for Pesticide Suicide Prevention, University of Edinburgh, QMRI

E3.22a, 47 Little France Crescent, Edinburgh EH16 4TJ, UK

${ }^{3}$ Pharmacology, Toxicology \& Therapeutics, University/BHF Centre for

Cardiovascular Science, University of Edinburgh, Edinburgh, UK

Full list of author information is available at the end of the article
}

(c) The Author(s). 2021 Open Access This article is licensed under a Creative Commons Attribution 4.0 International License, which permits use, sharing, adaptation, distribution and reproduction in any medium or format, as long as you give appropriate credit to the original author(s) and the source, provide a link to the Creative Commons licence, and indicate if changes were made. The images or other third party material in this article are included in the article's Creative Commons licence, unless indicated otherwise in a credit line to the material. If material is not included in the article's Creative Commons licence and your intended use is not permitted by statutory regulation or exceeds the permitted use, you will need to obtain permission directly from the copyright holder. To view a copy of this licence, visit http://creativecommons.org/licenses/by/4.0/ The Creative Commons Public Domain Dedication waiver (http://creativecommons.org/publicdomain/zero/1.0/) applies to the data made available in this article, unless otherwise stated in a credit line to the data. 


\section{Introduction}

Pesticide poisoning affects peoples' lives and health, particularly in low- and middle-income countries (LMIC) where high proportions of the population are engaged in agriculture and use highly hazardous pesticides (HHPs $[1,2])$ on a daily basis. There is a growing international acceptance that rapidly reducing and progressively eliminating exposure to toxic chemicals is essential for the protection of human rights, health, and lives, and for achieving the Sustainable Development Goals (SDGs) [3, 4]. Both the World Health Organization (WHO) and Food and Agriculture Organization of the United Nations (FAO) stress their commitment to pesticide risk reduction, including a progressive ban of HHPs [5].

HHPs have been responsible for an estimated 14 million premature deaths from pesticide suicide since the Green Revolution placed them into rural households completely unable to use or store them safely [6]. Data from Sri Lanka [7-9], Bangladesh [10], South Korea [11] and Kerala (India) [12] indicate that pesticide regulation to remove HHPs from agriculture results in marked reductions in pesticide suicides without apparent effect on agricultural yield. Means restriction works for highly lethal suicide methods, such as poisoning with HHPs, because it puts space and time between the person and means, allowing the suicide impulse to pass or selection of a less lethal means, increasing the chance of survival $[13,14]$.

Nepal is a South Asian LMIC with the population of 29 million that is heavily dependent on agriculture. According to the WHO, it has a high suicide rate of around 20/100,000 per year in 2012 [13]. Poisoning is a common cause of suicide [15-17], with pesticides the most important poison $[18,19]$. Pesticides are commonly used in Nepalese agriculture; they are regulated by the Plant Quarantine and Pesticide Management Centre (PQPM C) within the Ministry of Agriculture and Livestock Development (Box 1).

There are no nationwide data on the incidence of acute pesticide poisoning or of the pesticides causing deaths in Nepal [16, 20]. The Ministry of Health and Population collects data on poisoning but groups all poisons and forms (intentional, accidental, or occupational) of poisoning together, limiting the possibility for analysis. The Nepal Police records the numbers of suicides by poisoning, but again does not distinguish the agent. The Government of Nepal's Heath Management Information System (HMIS) does not include the detailed information on poisoning and suicides that would make comprehensive data collection possible. Record-keeping at hospitals is under-resourced, limiting its usefulness for analysis of the precise poisons involved in cases and deaths [20].

The aim of this work was to identify the pesticide regulation that has been performed in Nepal, to identify pesticides responsible for most poisonings, and to relate these to the incidence of poisoning suicides over the last 40 years in the country.

\section{Text Box 1. Pesticide regulation in Nepal}

Nepal passed its first Pesticide Act in 1991 [21]. The Pesticide Rules were approved in January 1993 and became operative with the Act on 16 July 1994. The Act regulates the import, manufacture, sales, distribution and use of pesticides within Nepal. It also established a Pesticide Committee composed of members from various ministries, the Pesticide Association of Nepal, scientists and consumer groups for the purpose of managing pesticide-related issues.

In 2015-2019, Nepal underwent an administrative and government reform, adopting a new Constitution in 2015, new Criminal and Civil Codes in 2017, and importantly a new Pesticide Management Act in 2019. The new Constitution changed the unitary administrative system to a federal system, with governance at federal, provincial, and municipal levels.

Pesticide management is delegated to the PQPMC of the Ministry of Agriculture and Livestock Development (MoALD). It was set up as part of structural reforms in 2018 to strengthen the government's commitment to pesticide management. It is responsible for federal pesticide management to oversee the implementation of the Pesticide Management Act including registration, reregistration, de-registration, and banning of pesticides as well as the coordination and administration of the Pesticide Management Committee. PQPMC is Nepal's Designated National Authority for the Rotterdam Convention.

Nepal's provinces obtained a mandate to engage with pesticide management with the new legislation, with creation of provincial Ministries for Land Management, Agriculture and Cooperative. Provinces can formulate their own Pesticide Committees and have powers to renew pesticide licenses. There are two bodies under each provincial Ministry responsible for pesticide management - Provincial Training Directorate and Provincial Agriculture Development Directorate (PADD). Each PADD has a number of Agriculture Knowledge Centres (AKCs) established in place of previous District Agriculture Development Offices. The AKCs are involved in knowledge sharing related to production of agricultural products, and in connecting researchers and farmers, and transferring technology by training.

According to the law, provincial powers include reregistration of pesticides (as opposed to registration, which is possible only on the federal level), registration of home-made botanical pesticides and promotion of bio-pesticide production in the country, as well as strengthening provisions for pesticide disposal. Provincial pesticide management committees can also issue 
licenses for distribution, storing, use and application of pesticides. The new provincial mandate is still under development.

In 2016, Nepal also developed a voluntary Code of Practice for Using Pesticides - a non-binding document based on the FAO's International Code of Conduct on Pesticide Management [22]. The Code of Practice provides practical guidance to public and private sector organisations involved in the pesticide life-cycle, from production (manufacture and formulation) to disposal. It aims to minimize adverse health and environmental effects as well as human and animal exposure. It is intended to serve as a guiding framework for strengthening the capacity of stakeholders to regulate, evaluate, and enforce effective control over pesticides.

\section{Methods}

Nepal's data on pesticide registration, use, and bans were obtained from the PQPMC website and from PQPMC officials. Suicide data were extracted from the Police and National Statistical Bureau reports for the years 1980 to 2019. The methods used in recording suicides are classified into seven categories: hanging, poisoning, weapon and instruments, drowning, burning, jumping, and electric current. The poisoning classification includes poisoning with substances other than pesticides (i.e. drugs and medicines). We used the World Bank data on the population of Nepal for each year from 1980 to 2019 as the denominator to calculate crude suicide rates.

We reviewed the literature for all papers reporting pesticide poisoning in Nepal from 1980 to 2019. We hand-searched Nepalese language and national journals for studies. We systematically searched PubMed and www.google.com for studies on pesticide and poisoning in Nepal using the search terms "Nepal" and "poisoning". We selected English language papers reporting primary studies with the aim to identify the compounds responsible for pesticide poisoning. There were no publication date restrictions. We reviewed the first 150 hits found on www.google.com until no new studies were revealed compared to the PubMed search.

\section{Statistical analysis}

Simple descriptive statistics were used to describe the data.

\section{Results}

Pesticides

Nepal uses relatively little pesticide compared to other countries. According to the Ministry of Agriculture and Livestock Development, the country uses 0.396 active ingredient (a.i.) $\mathrm{kg}$ of pesticide per hectare of land, in comparison to 0.481 a.i. $\mathrm{kg} / \mathrm{ha}$ in India and $1.9 \mathrm{~kg} / \mathrm{ha}$ in Europe [23]. However, pesticide imports are increasing (from 56 metric tons in 1997-8 to 809 tons in 2018-19, Fig. 1). Gross sales and values account for US $\$ 7.5$ million per year. These values do not take into account smuggling of pesticides across the border from India [21].

There are currently 171 pesticides registered in the country. According to the WHO hazard classification [24], one $(0.6 \%)$ is extremely hazardous (WHO class Ia), one $(0.6 \%)$ highly hazardous (WHO class Ib), 73 (42.44\%) moderately hazardous (WHO class II), 28 (16.27\%) slightly hazardous (WHO class III), and 68 unlikely to present acute hazard (WHO class U) (Table 1).

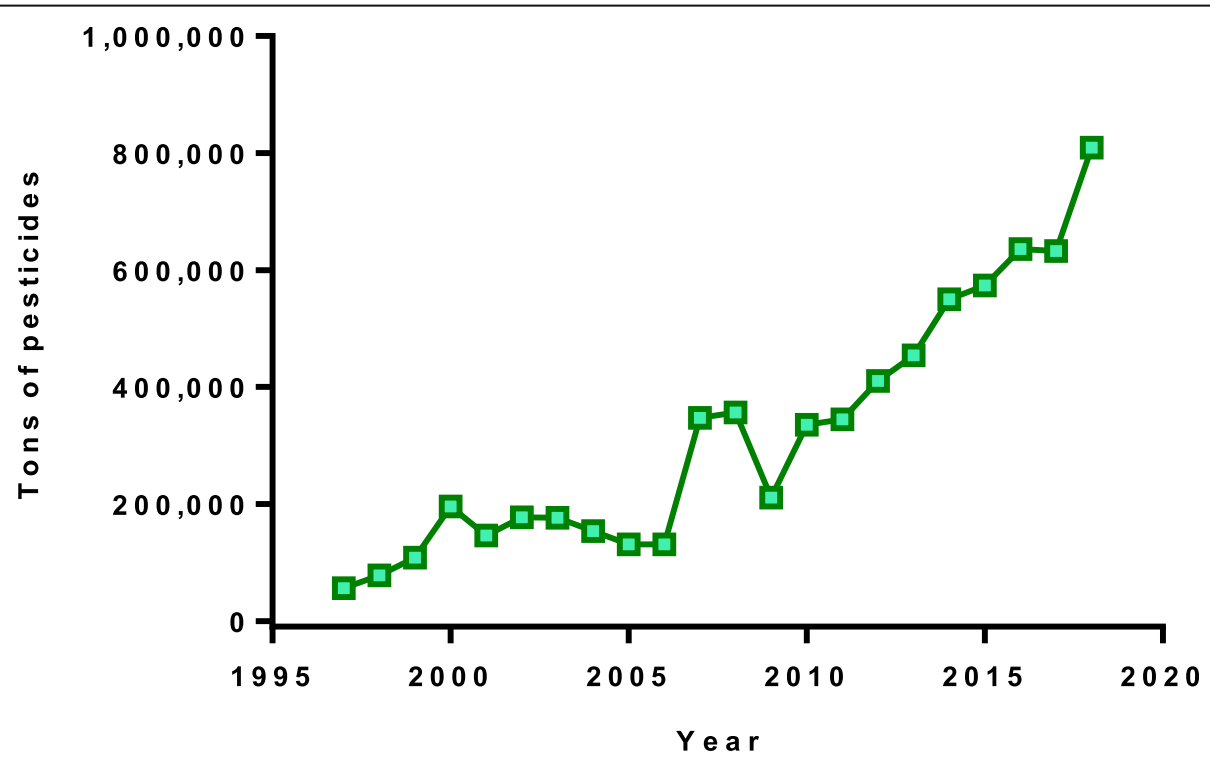

Fig. 1 National trends of pesticide imports. (Source: Plant Quarantine and Pesticide Management Centre, data available from authors upon request) 
Table 1 Classification of registered pesticides by WHO toxicity category

\begin{tabular}{|c|c|c|c|c|c|c|c|c|}
\hline WHO class & Insecticide & Acaricide & Fungicide & Herbicide & Rodenticide & Biopesticide & Others $^{a}$ & Total \\
\hline la & & & & & 1 & & & 1 \\
\hline lb & & & & & 1 & & & 1 \\
\hline II & 43 & 3 & 15 & 11 & & & 1 & 73 \\
\hline III & 11 & 1 & 6 & 7 & & 1 & 2 & 28 \\
\hline NC & 1 & & & & & & & 2 \\
\hline U & 4 & 2 & 22 & 12 & & 13 & 13 & 66 \\
\hline Total & 61 & 6 & 43 & 30 & 2 & 14 & 16 & 171 \\
\hline
\end{tabular}

a Others includes bactericides, herbal pesticides, molluscicides, and nematicides

WHO hazard class la pesticide: 1; class lb pesticides: the anticoagulant rodenticide bromadiolone (rodenticide) is a hazard class la compound while the rodenticide zinc phosphide is hazard class Ib.

Twenty-four pesticides have been banned in Nepal, the majority are persistent organic pollutant (POP) organochlorine compounds that were banned in 2001 and 2019 following adoption of the Stockholm Convention on Persistent Organic Pollutants (Table 2). Ten of the banned pesticides are obsolete and not used in agriculture and public health. In 2006, methyl parathion and monocrotophos were banned; two other acutely toxic HHPs (endosulfan and phorate) were banned in 2012 and 2015.

In 2019, the Pesticide Registration Board banned eight pesticides including the high concentration (56\%) $3 \mathrm{~g}$

Table 2 Pesticides banned in Nepal

\begin{tabular}{|c|c|c|c|}
\hline Pesticide & Year & WHO hazard class & Cited reason for ban \\
\hline Chlordane & 2001 & $\|$ & $\begin{array}{l}\text { Complying with Stockholm Convention banning of Persistent Organic } \\
\text { Pollutant }\end{array}$ \\
\hline Dieldrin & 2001 & (O) Obsolete not classified & $\begin{array}{l}\text { Complying with Stockholm Convention banning of Persistent Organic } \\
\text { Pollutant }\end{array}$ \\
\hline Aldrin & 2001 & (O) Obsolete not classified & $\begin{array}{l}\text { Complying with Stockholm Convention banning of Persistent Organic } \\
\text { Pollutant }\end{array}$ \\
\hline Mirex & 2001 & (O) Obsolete not classified & Complying with Stockholm convention banning of Persistent Organic Pollutant \\
\hline Lindane & 2001 & $\|$ & Complying with Stockholm convention banning of Persistent Organic Pollutant \\
\hline Phosphamidon & 2001 & la & Complying with Stockholm convention banning of Persistent Organic Pollutant \\
\hline DDT & 2001 & $\|$ & Complying with Stockholm convention banning of Persistent Organic Pollutant \\
\hline Endrin & 2001 & (O) Obsolete not classified & Complying with Stockholm convention banning of Persistent Organic Pollutant \\
\hline Heptachlor & 2001 & (O) Obsolete not classified & Complying with Stockholm convention banning of Persistent Organic Pollutant \\
\hline $\mathrm{BHC}$ & 2001 & (O) Obsolete not classified & Complying with Stockholm convention banning of Persistent Organic Pollutant \\
\hline Organomercury fungicides & 2001 & la & Complying with Stockholm convention banning of Persistent Organic Pollutant \\
\hline Toxaphene & 2001 & (O) Obsolete not classified & Complying with Stockholm convention banning of Persistent Organic Pollutant \\
\hline Monocrotophos & 2006 & $\mathrm{lb}$ & Highly hazardous to human health and environment \\
\hline Methyl parathion & 2006 & la & Highly hazardous to human health and environment \\
\hline Endosulfan & 2012 & $\|$ & Highly hazardous to fish and environment \\
\hline Phorate & 2015 & la & Highly hazardous to human health and environment \\
\hline Carbofuran & 2019 & $\mathrm{lb}$ & Highly hazardous to human health and environment \\
\hline Dichlorvos & 2019 & $\mathrm{lb}$ & Minimize suicide due to poisoning \\
\hline Triazophos & 2019 & $\mathrm{lb}$ & Highly hazardous to human health and environment \\
\hline Carbaryl & 2019 & $\|$ & Highly hazardous to human health and environment \\
\hline Benomyl & 2019 & $U$ & Highly hazardous to human health and environment \\
\hline Carbosulfan & 2019 & $\|$ & Highly hazardous to human health and environment \\
\hline Dicofol & 2019 & ॥ & Complying with Stockholm convention banning of Persistent Organic Pollutant \\
\hline $\begin{array}{l}\text { Aluminum phosphide } 3 \mathrm{~g} \\
\text { tablet }\end{array}$ & 2019 & $\begin{array}{l}\text { FM (Fumigant not } \\
\text { classified) }\end{array}$ & To minimize suicide cases \\
\hline
\end{tabular}


Table 3 Reported Nepalese stockpiles of recently banned pesticides (December 2019)

\begin{tabular}{lll}
\hline $\mathbf{1}$ & Carbofuran & $\mathbf{6 4 , 0 0 0 ~ \mathbf { ~ g }}$ \\
\hline 2 & Aluminum phosphide tablet $3 \mathrm{~g}$ & $32,500 \mathrm{~kg}$ \\
3 & Dichlorvos & $44,000 \mathrm{Lt}$ \\
4 & Triazophos & $1200 \mathrm{Lt}$ \\
5 & Benomyl & 0 \\
6 & Carbaryl & 0 \\
\hline
\end{tabular}

tablet form of aluminum phosphide as well as several pesticides important for suicide in South Asia (carbofuran, carbosulfan, dichlorvos, and triazophos) (Table 2). Import and production was banned from August 4th, 2019. During the following two years, stockpiles in the country (Table 3) can be sold to farmers; after the twoyear phase out period, all remaining stockpiles will need to be deposited in a government-built warehouse.

\section{Suicides}

Suicidal deaths reported to the police have been increasing steadily in the past years (Fig. 2). In 2018-2019, 5754 deaths were reported, compared to 5317 in 20172018 and 5124 in 2016-2017 [25]. The calculated annual crude suicide rate in 2018-2019 was 20.7/100,000. The number of suicides in 1980 was recorded as 247 . The rate of suicide increased from $1.64 / 100,000$ in 1980 to 20.72/100,000 in 2018-19 (1163\% increase).

According to the police data, the most common method of suicide was hanging $(4312,74.1 \%)$ in $2018-$ 19 . Suicide by poisoning $(n=1320)$ accounted for $22.9 \%$ of suicides in the same period [25]. Between 1980 and 2019, hanging and poisoning accounted for 51,749 (66.1\%) and 22,153 (28.3\%) of all suicide deaths respectively. Hanging accounted for the majority of the increase in suicide rate, increasing from 155 in $1980(1.03 / 100$, $000)$ to 4312 in $2018-19(15.35 / 100,000)$ (1390\% increase, Fig. 2). The rate of increase in poisoning suicides was less, from 55 in $1980(0.37 / 100,000)$ to 1320 in 2018-19 (4.7/100,000) (1170\% increase in rate), with most of the increase occurring in 1995-2003, and in 2008-12. Poisoning suicide numbers have been stable over the last 8 years, while hanging has increased greatly.

\section{Pesticides involved in suicides}

Our search identified 50 relevant publications ([17, 2674]) (Fig. 3 and Table 4). Studies were published between 1990 and 2020. Most were hospital-based studies published in Nepalese academic journals. The number of poisoned patients in each publication ranged from 37 [26] to 2621 [37].

All the papers reported Organophosphorus (OP) insecticides to be responsible for most poisonings, ranging from $39.6 \%$ [58] to $65.0 \%$ of all poisonings [30], but most did not report the exact pesticides used. The second most common poisoning was with aluminium or zinc phosphide (10.7 to $26.1 \%)$. Few cases of poisoning and very few fatal cases in these papers were due to nonpesticide poisons. From 87 to $97 \%$ of poisoning patients in each publication was due to intentional poisoning. Mortality varied between 3 and $18.7 \%$.

Among the studies that determined the OP pesticide used, methyl parathion and dichlorvos were the most common in all studies reviewed (Table 4). Depending on the study, methyl parathion (Metacid) accounted for $12.9 \%$ (2005-2011) [74], 17.5\% (2004) [68], 52\% (2012) [73] and 65-68\% (2003-2005 and 2016-2018) [38, 61] of all OP insecticide poisonings (Table 4). Dichlorvos (Nuvan) was the compound used in 17 to $24 \%$ of OP poisoning. Malathion was the third most commonly

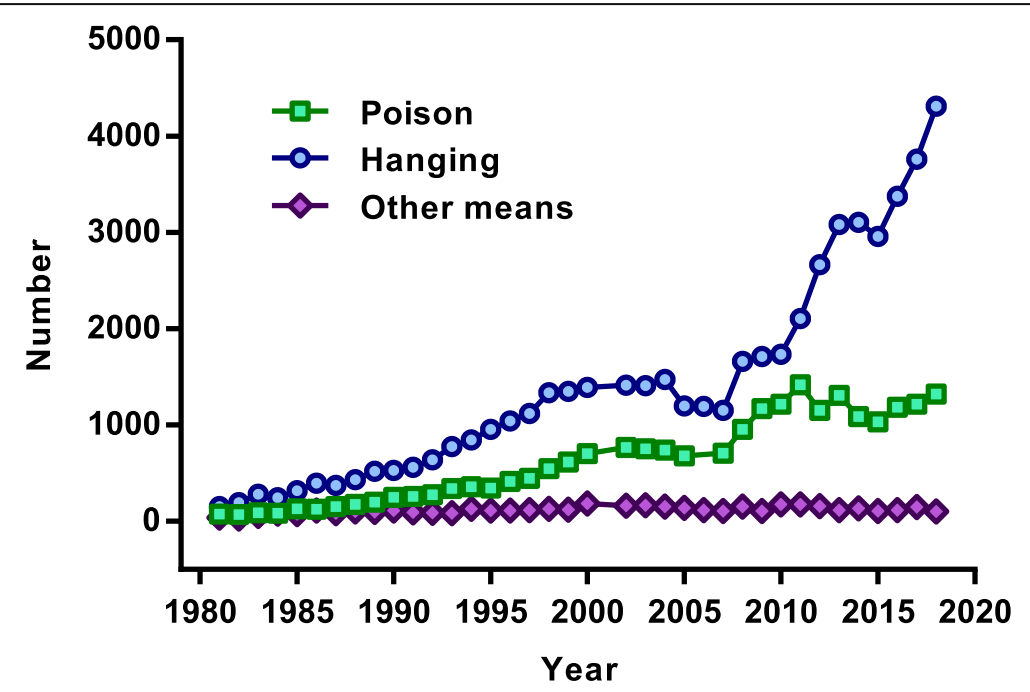

Fig. 2 Suicide numbers in Nepal 1980-2019. (Source: Nepal police, data available from the authors upon request) 


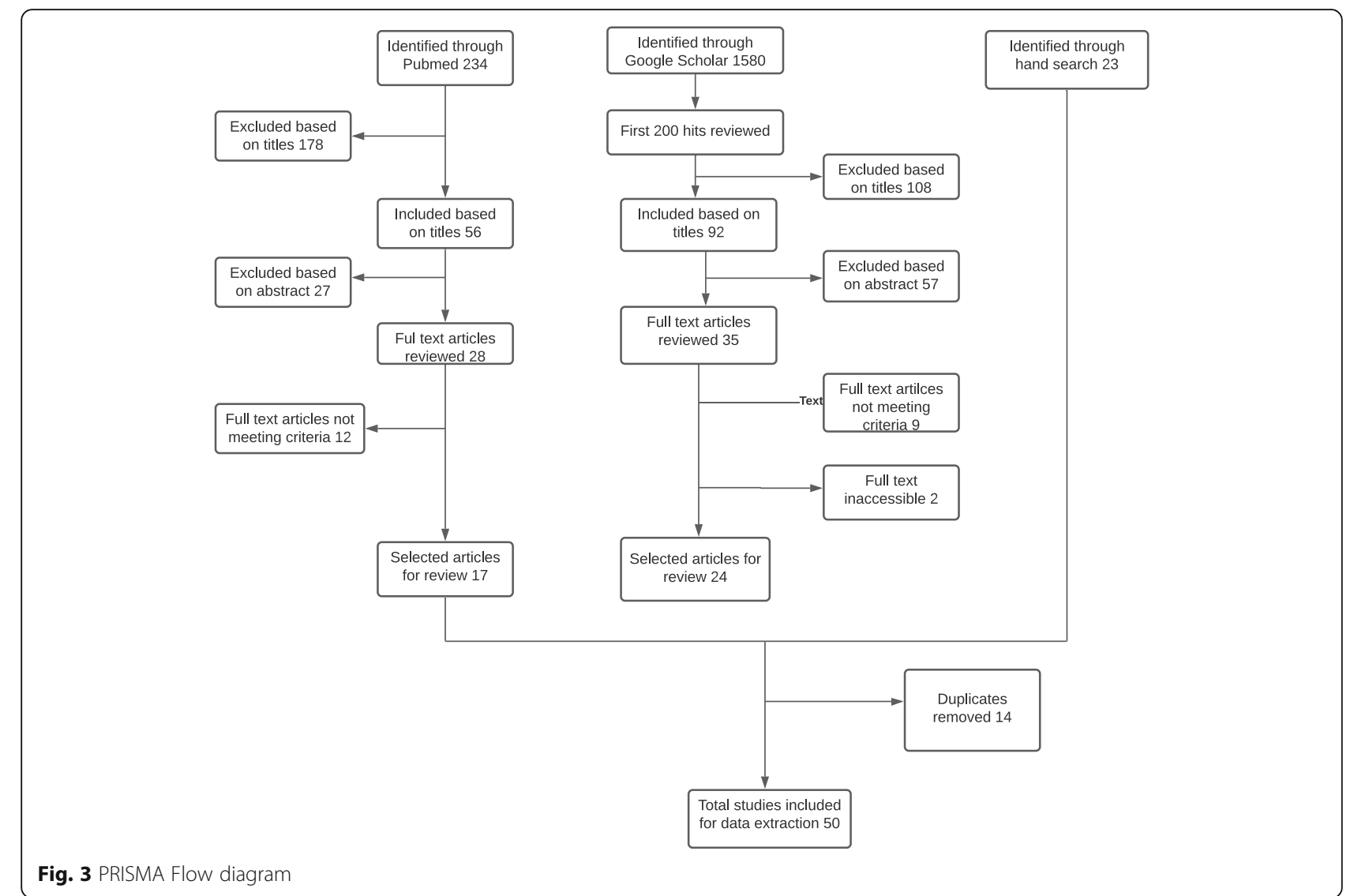

used OP agent for poisoning [73]. Monocrotophos was not reported in any publication.

\section{Discussion}

There is no systematic system for suicide surveillance in Nepal [20]. Suicide and attempted suicide cases need to be reported to the police but due to the stigma and perceived (not actual) illegality of the act, many cases are believed to not be reported, leading to under-reporting of national data $[16,20]$. In addition, there is misclassification as well as gaps in hospital record-keeping. This is a common situation across South Asia in countries with an uncertain legal status for suicide [75]. A small anomaly in Nepal is that group suicides are recorded by the police as a single suicide, further reducing numbers.

The WHO presents a wide range of competing estimates for suicide in Nepal, both considerably higher and lower than the official statistics. In 2014, the WHO modelled a 2012 predicted suicide rate, ranking Nepal 7 th in the world at 24.9 per 100,000 , the $3 \mathrm{~d}$ highest for women $(20$ per 100,000$)$ and 17 th for men $(30.1$ per 100 , 000) [13]. In contrast, the WHO Global Health Estimates for 2019 reports 2544 suicides in Nepal (markedly lower than the 5819 reported by the police), of which $1176(8.0 / 100,000)$ occurred in females and 1368 (11.4) occurred in males. This equates to an overall suicide rate of 9.6/1000,000, lower than the mean global rate of $10.5 /$ 100,000 population [13]. The discrepancy in numbers shows the importance of developing reliable national data on suicides and pesticide suicides.

Nepal's hospital staff have difficulties identifying the compounds responsible for poisoning for patients who present to hospitals. In most cases, when the poisoning agent is recorded in hospital records, the patient or their family brought the containers to the hospital. When the compound used is not known, the atropine challenge test is used to determine if the patient ingested an OP chemical [37]. For the non-OP pesticides, the diagnosis is usually based on the container or information from the patient or family. In cases of OP poisoning determined by the atropine challenge test, the exact compound is usually unknown. If there is no container of the ingested compound and the atropine challenge is negative, the name of the agent is not indicated in the medical notes, making it difficult to identify the responsible agent.

We found that the number of suicides in Nepal have increased markedly since 1980, mostly due to a great increase in suicides from hanging. Pesticide suicides have made up about $1 / 4$ of suicides during this time but have not increased in number to the same extent. The most 
Table 4 Pesticides identified in case series of pesticide self-poisoning in Nepal 1980-2019

\begin{tabular}{|c|c|c|c|c|c|c|}
\hline \# & $\begin{array}{l}\text { Year } \\
\text { [ref] }\end{array}$ & Location & $\begin{array}{l}\text { Pesticide cases /out of total } \\
\text { number of patients }\end{array}$ & Pesticide classes & Compounds identified & $\begin{array}{l}\text { Fatalities with responsible } \\
\text { compound (where identified) }\end{array}$ \\
\hline 1 & $\begin{array}{l}1995- \\
1996[26]\end{array}$ & Dharan & $37 / 37$ & All OP & 23 Methyl parathion & Not identified \\
\hline 2 & 2000 [29] & $\begin{array}{l}\text { Kathmandu } \\
\text { Pokhara } \\
\text { Dharan }\end{array}$ & $256 / 256$ & $133 \mathrm{OP}$ & $\begin{array}{l}80 \text { Methyl parathion } \\
53 \text { Dichlorvos } \\
29 \text { Zinc phosphide } \\
18 \text { Aluminum phosphide }\end{array}$ & $42(16.2 \%)$ cases. \\
\hline 3 & $\begin{array}{l}2003-5 \\
{[38]}\end{array}$ & Kathmandu & $47 / 47$ & $47 \mathrm{OP}$ & 32 Methyl parathion & 3 fatalities \\
\hline 4 & $\begin{array}{l}2003- \\
2006[32]\end{array}$ & Dhulikhel & $59 / 59$ & All OP & $\begin{array}{l}15 \text { Dichlorvos } \\
13 \text { Methyl parathion }\end{array}$ & \\
\hline 5 & $\begin{array}{l}2003-6 \\
{[33]}\end{array}$ & Pokhara & $56 / 98$ & $\begin{array}{l}32(31.68 \%) \text { Rodenticides } \\
15(14.85 \%) \text { OP } \\
\text { insecticides }\end{array}$ & Not identified & $\begin{array}{l}\text { 5/32 Rodenticides } \\
4 / 15 \text { OP insecticides }\end{array}$ \\
\hline 6 & $2004[34]$ & Kathmandu & $154 / 154$ & $\begin{array}{l}65 \text { OP } \\
38 \text { Drugs } \\
10 \text { Zinc phosphide } \\
6 \text { Aluminum phosphide } \\
2 \text { Carbamate }\end{array}$ & $\begin{array}{l}31 \text { Dichlorvos } \\
27 \text { Methyl parathion }\end{array}$ & 4/7 Methyl parathion \\
\hline 7 & $\begin{array}{l}2004-5 \\
{[72]}\end{array}$ & Kathmandu & $50 / 50$ & All OP poisoning & $\begin{array}{l}\text { 34/50 Methyl parathion } \\
\text { 13/50 Dichlorvos }\end{array}$ & $7(14 \%)$ \\
\hline 8 & $2005[35]$ & Kathmandu & $74 / 99$ & $\begin{array}{l}63 \text { Insecticides } \\
11 \text { Rodenticides }\end{array}$ & $\begin{array}{l}21 \text { Methyl parathion } \\
16 \text { Dichlorvos } \\
5 \text { Aluminium phosphide }\end{array}$ & $\begin{array}{l}\text { 2/21 Methyl parathion } \\
\text { 1/16 Dichlorvos }\end{array}$ \\
\hline 9 & $\begin{array}{l}2005- \\
2008[36]\end{array}$ & Dharan & $73 / 122$ & $\begin{array}{l}55(45.1 \%) \text { OP } \\
10(8.2 \%) \\
\text { Organochlorine } \\
\text { insecticides } \\
4 \text { Cypermethrin } \\
3 \text { Zinc phosphide } \\
1 \text { Carbamate }\end{array}$ & Not identified & $12.6 \%$ \\
\hline 10 & $\begin{array}{l}2005- \\
2010[37]\end{array}$ & Dharan & $1661 / 2621$ & $\begin{array}{l}1101(67 \%) \text { OP } \\
321 \text { Organochlorine } \\
\text { insecticides } \\
182(10.96 \%) \\
\text { Rodenticide }\end{array}$ & Not identified & $\begin{array}{l}168(6.41 \%) \text { fatal } \\
156 \text { OP } \\
6 \text { Zinc phosphide }\end{array}$ \\
\hline 11 & $\begin{array}{l}2005-11 \\
{[74]}\end{array}$ & Kathmandu & $190 / 354$ & $\begin{array}{l}150 \text { OP } \\
40 \text { Rodenticides } \\
71 \text { Medicine }\end{array}$ & 61 Methyl parathion & $\begin{array}{l}19 \text { OP } \\
1 \text { Rodenticide }\end{array}$ \\
\hline 12 & $\begin{array}{l}2006- \\
2010[39]\end{array}$ & Pokhara & $25 / 94$ & $\begin{array}{l}6 \text { OP Carbamates } \\
3 \text { Rodenticide }\end{array}$ & 6 Methyl parathion & 1 Methyl parathion \\
\hline 13 & $\begin{array}{l}2006- \\
2012[40]\end{array}$ & Pokhara & $34 / 187$ & $\begin{array}{l}30 \text { OP } \\
4 \text { Carbamates }\end{array}$ & $\begin{array}{l}9 \text { Methyl parathion } \\
5 \text { Dichlorvos } \\
1 \text { Malathion } \\
3 \text { Propoxur (baygon) }\end{array}$ & $\begin{array}{l}\text { 1/9 Methyl parathion } \\
\text { 1/3 Propoxur }\end{array}$ \\
\hline 14 & $2007[42]$ & Dhulikhel & $54 / 54$ & $\begin{array}{l}40 \text { OP } \\
3 \text { Zinc phosphide }\end{array}$ & $\begin{array}{l}21 \text { Methyl parathion } \\
16 \text { Dichlorvos }\end{array}$ & $5,5 \%$ fatal \\
\hline 15 & 2007 [43] & Chitwan & $182 / 921$ & $\begin{array}{l}\text { Snake bite } 366(39.7 \%) \\
\text { Insecticide } 182(19.8 \%)\end{array}$ & $\begin{array}{l}84 \text { OP } \\
58 \text { Zinc phosphide } \\
21 \text { Cypermethrin } \\
6 \text { Aluminum phosphide }\end{array}$ & Not identified \\
\hline 16 & $\begin{array}{l}2007- \\
2008[44]\end{array}$ & Kathmandu & $41 / 148$ & $\begin{array}{l}29 \text { OP } \\
12 \text { Zinc phosphide }\end{array}$ & 12 Zinc phosphide & \\
\hline 17 & $\begin{array}{l}2008- \\
2011[45]\end{array}$ & Kathmandu & $11 / 35$ & $\begin{array}{l}6 \text { OP } \\
1 \text { Zinc phosphide } \\
1 \text { Organochlorine }\end{array}$ & Not identified & Not identified \\
\hline 18 & $2008[71]$ & Pokhara & $65 / 65$ & All OP & $\begin{array}{l}42 \text { Methyl parathion } \\
11 \text { Baygone spray } \\
6 \text { Dichlorvos }\end{array}$ & Not identified \\
\hline
\end{tabular}


Table 4 Pesticides identified in case series of pesticide self-poisoning in Nepal 1980-2019 (Continued)

\begin{tabular}{|c|c|c|c|c|c|c|}
\hline$\#$ & $\begin{array}{l}\text { Year } \\
\text { [ref] }\end{array}$ & Location & $\begin{array}{l}\text { Pesticide cases /out of total } \\
\text { number of patients }\end{array}$ & Pesticide classes & Compounds identified & $\begin{array}{l}\text { Fatalities with responsible } \\
\text { compound (where identified) }\end{array}$ \\
\hline & & & & & 3 Malathion & \\
\hline 19 & $\begin{array}{l}2008- \\
2011[46]\end{array}$ & Pokhara & $96 / 160$ & $\begin{array}{l}67 \text { OP } \\
23 \text { Rodenticide } \\
6 \text { Cypermethrin }\end{array}$ & Not identified & $\begin{array}{l}8 \text { OP } \\
1 \text { rodenticide } \\
2 \text { cypermethrin }\end{array}$ \\
\hline 20 & $2010[48]$ & Chitwan & $88 / 178$ & $\begin{array}{l}19 \text { OP } \\
3 \text { Organochlorine } \\
5 \text { Cypermethrin } \\
6 \text { Phosphides }\end{array}$ & $\begin{array}{l}5 \text { Cypermethrin } \\
6 \text { Phosphide } \\
3 \text { Endosulfan }\end{array}$ & $\begin{array}{l}\text { 3/19 OP } \\
2 \text { Endosulfan } \\
1 \text { Phosphide }\end{array}$ \\
\hline 21 & $\begin{array}{l}2010-11 \\
{[73]}\end{array}$ & Birgunj & $171 / 171$ & all OP & $\begin{array}{l}89 \text { Methyl parathion } \\
22 \text { Malathion } \\
30 \text { Dichlorvos } \\
12 \text { Baygon spray } \\
18 \text { Unknown }\end{array}$ & 18.71\% mortality \\
\hline 22 & $\begin{array}{l}2010- \\
2011[66]\end{array}$ & Dharan & $32 / 149$ & $\begin{array}{l}30 \text { OP } \\
2 \text { Aluminum phosphide }\end{array}$ & 2 Aluminum phosphide & $\begin{array}{l}\text { All (study of postmortem } \\
\text { cases) }\end{array}$ \\
\hline 23 & $\begin{array}{l}2011-12 \\
{[50]}\end{array}$ & Kavre & $91 / 137$ & $56 \mathrm{OP}$ & $\begin{array}{l}17 \text { Aluminum phosphide } \\
18 \text { Methyl parathion / } \\
\text { Dichlorvos }\end{array}$ & 4/137 Unknown \\
\hline 24 & $\begin{array}{l}2012-13 \\
{[63]}\end{array}$ & Dharan & 763/1399 & $\begin{array}{l}398 \text { OP } \\
16 \text { Fertiliser }\end{array}$ & $\begin{array}{l}332 \text { OP } \\
175 \text { Phosphide } \\
66 \text { OP in combination } \\
190 \text { Organochlorine }\end{array}$ & $5,1 \%$ \\
\hline 25 & $\begin{array}{l}2013- \\
2015[51]\end{array}$ & Rupandehi & 72/107 & $\begin{array}{l}21(19.63 \%) \text { OP } \\
27(25.23 \%) \\
\text { Cypermethrin } \\
9 \text { Rodenticide }\end{array}$ & $\begin{array}{l}27 \text { Cypermethrin } \\
9 \text { Dichlorvos }\end{array}$ & 5/107 fatal \\
\hline 26 & $\begin{array}{l}2013- \\
2017[52]\end{array}$ & Kathmandu & $87 / 144$ & $\begin{array}{l}75 \text { OP } \\
11 \text { Drugs } \\
11 \text { Rodenticide } \\
1 \text { Fungicide }\end{array}$ & $\begin{array}{l}16 \text { Dichlorvos } \\
14 \text { Methyl parathion } \\
13 \text { Cypermethrin } \\
13 \text { Chlorpyrifos + } \\
\text { Cypermethrin } \\
6 \text { Chlorpyrifos } \\
5 \text { Dimethoate }\end{array}$ & $\begin{array}{l}7(4.9 \%) \text { fatal } \\
\text { 3/16 Dichlorvos } \\
1 \text { Aluminum phosphide }\end{array}$ \\
\hline 27 & 2014 [53] & Kathmandu & $110 / 84$ & $\begin{array}{l}64 \text { OP } \\
20 \text { Zinc sulphide }\end{array}$ & Not identified & $4(6.25 \%)$ \\
\hline 28 & $\begin{array}{l}2014- \\
2016[55]\end{array}$ & Lumbini & $38 / 65$ & $\begin{array}{l}21 \text { OP } \\
17 \text { Zinc phosphide }\end{array}$ & 17/38 Zinc phosphide & \\
\hline 29 & $\begin{array}{l}2014- \\
2017[56]\end{array}$ & Lumbini & $87 / 138$ & $\begin{array}{l}50 \text { OP } \\
23 \text { Rodenticide } \\
2 \text { Fungicide }\end{array}$ & Not identified & $1 / 50 \mathrm{OP}$ \\
\hline 30 & 2015 [57] & Kathmandu & $84 / 84$ & All OP & $\begin{array}{l}48 \text { Dichlorvos } \\
20 \text { Methyl parathion } \\
10 \text { Cypermethrin + } \\
\text { Chlorpyrifos } \\
4 \text { Triazophos + } \\
\text { Deltamethrin }\end{array}$ & 8 fatal \\
\hline 31 & 2015 [62] & Dharan & $35 / 57$ & $\begin{array}{l}20 \text { OP (24.6\%) } \\
15 \text { Zinc phosphide (14\%) }\end{array}$ & Not identified & 8.7\% mortality \\
\hline 32 & 2015 [58] & Chitwan & $439 / 439$ & $\begin{array}{l}263(59.9 \%) \text { Insecticides } \\
91(20.8 \%) \text { Rodenticide } \\
15(3.4 \%) \text { Herbicide } \\
5 \text { (1.1\%) Fungicide }\end{array}$ & $\begin{array}{l}174(39.6 \%) \text { OP } \\
154(35.1 \%) \text { Pyrethroid } \\
95(21.6 \%) \text { Zinc and } \\
\text { Aluminum phosphide } \\
\text { 4 Dinitrophenol derivative } \\
2 \text { Carbamate } \\
2 \text { Organochlorine }\end{array}$ & $16(3.8 \%)$ \\
\hline 33 & $\begin{array}{l}2015- \\
2016[64]\end{array}$ & Manipal & $78 / 78$ & $78 \mathrm{OP}$ & $\begin{array}{l}\text { Methyl parathion } 24 \\
(30.76 \%) \\
\text { Dichlorvos } 18 \text { (23.07\%) } \\
\text { Cypermethrin } 3(3.84 \%)\end{array}$ & $5.12 \%$ \\
\hline
\end{tabular}


Table 4 Pesticides identified in case series of pesticide self-poisoning in Nepal 1980-2019 (Continued)

\begin{tabular}{|c|c|c|c|c|c|c|}
\hline$\#$ & $\begin{array}{l}\text { Year } \\
\text { [ref] }\end{array}$ & Location & $\begin{array}{l}\text { Pesticide cases /out of total } \\
\text { number of patients }\end{array}$ & Pesticide classes & Compounds identified & $\begin{array}{l}\text { Fatalities with responsible } \\
\text { compound (where identified) }\end{array}$ \\
\hline & & & & & $\begin{array}{l}\text { Chlorpyrifos + } \\
\text { Cypermethrin } 8 \text { (10.25) }\end{array}$ & \\
\hline 34 & $\begin{array}{l}2015- \\
2017[59]\end{array}$ & Pokhara & $88 / 156$ & $\begin{array}{l}45 \text { (28.8\%) OP } \\
43 \text { (27.5\%) Rodenticide }\end{array}$ & Not identified & Not identified \\
\hline 35 & $\begin{array}{l}2016- \\
2018[60]\end{array}$ & Biratnagar & $58 / 85$ & $\begin{array}{l}37 \text { OP } \\
12 \text { Organochlorine } \\
9 \text { Zinc/al phosphide }\end{array}$ & Not identified & $\begin{array}{l}5 \text { OP } \\
10 \text { non-OP }\end{array}$ \\
\hline 36 & $\begin{array}{l}2016- \\
2018 \\
{[61]}\end{array}$ & Kathmandu & $210 / 210$ & All OP poisonings & Methyl parathion 65\% & $7.62 \%$ \\
\hline
\end{tabular}

important pesticides responsible for pesticide poisonings and deaths in the literature has been OP pesticides. Most frequently used was methyl parathion (Metacid); although banned in 2006, it still appears as widely used poisoning agent, suggesting that the pesticide may have come across the border from India. However, very few patients bring the pesticide bottles with them to hospital and the pesticide is named from memory. Since Metacid is a widely used pesticide, it is possible that the term Metacid is used generally for any pesticides as occurred in Sri Lanka with Folidol (another brand name for methyl-parathion) and then Tamaron (methamidophos). This habit may have led to an overestimation of the importance of methyl parathion as poisoning agent. Our recent data from forensic science laboratories which identify the actual compounds ingested in fatal poisoning suggest that methyl-parathion poisoning is not a significant problem in Nepal anymore (Ghimire et al., submitted).

The other important pesticides for fatal self-poisoning were dichlorvos and aluminum phosphide, which were either banned completely (dichlorvos) or high concentration formulations banned (aluminum phosphide) in 2019.

Other pesticides have become increasingly frequently identified as involved in pesticide poisoning, including cypermethrin, chlorpyrifos, and malathion. Since the historically most important pesticides for suicide (methylparathion, dichlorvos and aluminum phosphide tablets) are now banned in Nepal, it will be important to observe for changes in the Nepal's suicide rate. In this context, implementation of the regulations and elimination of the illegal sales become very important, as well as providing farmers with advice on substitution of banned pesticides. Based on data from elsewhere in Asia [76], these HHPs bans should result in a marked fall in pesticide suicides over the next $2-5$ years.

Nepal has been successful at reducing the number of HHPs used in its agriculture, despite the increase in use of pesticides. This likely accounts for the very low number of occupational poisoning cases we have found to be admitted in hospital in Nepal (Ghimire, submitted).
There are now only two WHO class Ia (bromadiolon) and Ib (Zinc Phosphide) pesticides left in use in Nepal. The necessity of their use should be reviewed by the PQPMC and removed if they cannot be used safely. As the recent bans are enacted and stockpiles run out, it will be important to see which WHO hazard class II insecticides become problematic for suicide, requiring an analysis of their need in agriculture.

\section{Limitations}

We used police data for suicide deaths. Due to stigma and fear of perceived negative consequences, this likely underrepresents the actual numbers of suicides. To identify the agent used for poisoning we reviewed the literature to identify the agents. This is less reliable than accurate hospital based collection of data on the poisoning agent and ideally identification of the actual compound through forensic toxicology laboratory analysis. In addition, there is misclassification as well as gaps in hospital record-keeping.

\section{Conclusion}

In the last twenty years (2001-2019), Nepal has banned many HHPs, including the ones that were commonly used for pesticide self-poisoning. During this time, the incidence of hanging has risen markedly with a much smaller increase in pesticide suicides, which might be related to the regulation. Research is now needed on the effect of the 2019 ban of eight pesticides, many of which have been key for pesticide suicides over the last 15 years.

\footnotetext{
Abbreviations

a.i: active ingredient; AKC: Agriculture Knowledge Centre; HHPs: Highly Hazardous Pesticides; HMIS: Health Management Information System; LMIC: Low-and Middle-Income Country; MoALD: Ministry of Agriculture and Livestock Development; OP pesticide: Organophosphorus pesticide; PADD: Provincial Agriculture Development Directorate; POP: Persistent Organic Pollutants; PQPMC: Plant Quarantine and Pesticide Management Centre; SDGs: Sustainable Development Goals; WHO: World Health Organization
} 


\section{Acknowledgements}

The authors would like to thank Mr. Biren Bangdel for assistance with conducting interviews. We are grateful to Dr. Neshan Rai and Ms. Manisha Pokhrel for their help in the systematic review.

\section{Authors' contributions}

ME conceptualized the study. ME and LU designed the study, acquired the data and drafted and revised the manuscript. AK performed the statistical analysis; DS, RG and GR contributed to the writing of the manuscript. All authors read and approved the final manuscript.

\section{Funding}

The Centre for Pesticide Suicide Prevention is funded by an incubation grant from the Open Philanthropy Project on the recommendation of GiveWell. The funders of the study had no role in study design, data collection, data analysis, data interpretation, or writing of the manuscript.

\section{Availability of data and materials}

Data and materials are available from Leah Utyasheva upon request.

\section{Declarations}

\section{Ethics approval and consent to participate}

Ethical approval was received from the Nepal Health Research Council on 24 January 2018 (Registration No 535/2017, Ref No. 2397).

This study used secondary data. No participants/ subjects were recruited for this study. All research methods were carried out in accordance with relevant guidelines and regulations.

\section{Consent for publication}

No identifiable data from patients were collected and will be published.

\section{Competing interests}

No competing interests are declared.

\section{Author details}

${ }^{1}$ Centre for Pesticide Suicide Prevention, University of Edinburgh, QMRI E3.22a, 47 Little France Crescent, Edinburgh EH16 4TJ, UK. ${ }^{2}$ Maharajgunj Medical Campus, Institute of Medicine, Tribhuvan University, Kathmandu, Nepal. ${ }^{3}$ Pharmacology, Toxicology \& Therapeutics, University/BHF Centre for Cardiovascular Science, University of Edinburgh, Edinburgh, UK.

\section{Received: 25 March 2021 Accepted: 26 May 2021}

\section{Published online: 14 June 2021}

\section{References}

1. Food and Agriculture Organization, World Health Organisation. The International Code of Conduct on Pesticide Management. Rome: FAO; 2014.

2. Food and Agriculture Organization, World Health Organization. Guidelines on Highly Hazardous Pesticides. Rome: Food and Agriculture Organisation; 2016.

3. Elver H. Report of the special rapporteur on the right to food. A/HRC/34/48. In. United Nations General Assembly: Human Rights Council; 2017.

4. $F A O$ and $W H O$. Detoxifying agriculture and health from highly hazardous pesticides - A call for action. Rome: FAO; 2019

5. Food and Agriculture Organization of the United Nations. International Code of Conduct on Pesticide Management. Guidelines on Highly Hazardous Pesticides. Rome: FAO; 2016.

6. Karunarathne A, Gunnell D, Konradsen F, Eddleston M. How many premature deaths from pesticide suicide have occurred since the agricultural Green Revolution? Clin Toxicol (Philadelphia, Pa). 2020;58(4):227-32.

7. Gunnell D, Fernando R, Hewagama M, Priyangika WDD, Konradsen F, Eddleston M. The impact of pesticide regulations on suicide in Sri Lanka. Int J Epidemiol. 2007;36(6):1235-42. https://doi.org/10.1093/ije/dym164.

8. Knipe DW, Gunnell D, Eddleston M. Preventing deaths from pesticide selfpoisoning - learning from Sri Lanka's success. Lancet Glob Health. 2017;5(7): e651-2. https://doi.org/10.1016/S2214-109X(17)30208-5.

9. Manuweera G, Eddleston M, Egodage S, Buckley NA. Do targeted bans of insecticides to prevent deaths from self-poisoning result in reduced agricultural output? Environ Health Perspect. 2008;1 16(4):492-5. https://doi. org/10.1289/ehp.11029.
10. Chowdhury FR, Dewan G, Verma VR, Knipe DW, I.T. I, Faiz MA, Gunnell DJ, et al. Bans of WHO class I pesticides in Bangladesh - suicide prevention without hampering agricultural output. Int J Epidemiol. 2017;47:175-84.

11. Cha ES, Chang SS, Gunnell D, Eddleston M, Khang YH, Lee WJ. Impact of paraquat regulation on suicide in South Korea. Int J Epidemiol. 2016;45(2): 470-9. https://doi.org/10.1093/ije/dyv304.

12. Bonvoisin T, Utyasheva L, Knipe D, Gunnell D, Eddleston M. Suicide by pesticide poisoning in India: a review of pesticide regulations and their impact on suicide trends. BMC Public Health. 2020;20(1):251. https://doi. org/10.1186/s12889-020-8339-z.

13. World Health Organization. Preventing suicide. A global imperative. Geneva: WHO; 2014.

14. Eddleston $M$, Gunnell D. Preventing suicide through pesticide regulation. Lancet Psychiatry. 2020;7(1):9-11. https://doi.org/10.1016/S2215-0366(19)30478-X.

15. Hagaman AK, Khadka S, Lohani S, Kohrt B. Suicide in Nepal: a modified psychological autopsy investigation from randomly selected police cases between 2013 and 2015. Soc Psychiatry Psychiatr Epidemiol. 2017;52(12): 1483-94. https://doi.org/10.1007/s00127-017-1433-6.

16. Marahatta K, Samuel R, Sharma P, Dixit L, Shrestha BR. Suicide burden and prevention in Nepal: the need for a national strategy. WHO South-East Asia J Public Health. 2017;6(1):45-9. https://doi.org/10.4103/2224-3151.206164.

17. Thapaliya S, Gupta AK, Tiwari S, Belbase M, Paudyal S. Pattern of suicide attempts in southern Nepal: a multi-centered retrospective study. MedPhoenix. 2018;3:41-7.

18. Joshi SK. Pesticides poisoning in Nepal (editorial). Kathmandu Univ Med J. 2003;1:157.

19. Tuladar BS. Trends of clinical toxicology cases in Nepal. J Forensic Res. 2014; 5:217.

20. Hagaman AK, Maharjan U, Kohrt BA. Suicide surveillance and health systems in Nepal: a qualitative and social network analysis. Int J Ment Heal Syst. 2016;10(1):46. https://doi.org/10.1186/s13033-016-0073-7.

21. Palikhe BR. Pesticide management in Nepal: in view of code of conduct. In: Regional workshop on International Code of Conduct on the Distribution and Use of Pesticides: implementation, monitoring and observance. Bangkok: FAO; 2005.

22. Food and Agriculture Organisation of the United Nations, World Health Organization. The International Code of Conduct on Pesticide Management. Rome: FAO; 2014

23. Sharma DR. Status of Chemical Pesticides Use and their Regulation in Nepal; 2019

24. World Health Organization. The WHO recommended classification of pesticides by hazard and guidelines to classification: 2009. Geneva: WHO; 2010.

25. Nepal Police Headquarters. Annual suicide numbers. In: Ghimire R, editor. Email communication; 2019.

26. Karki P, Hansdak SG, Bhandari S, Shukla A, Koirala S. A clinicoepidemiological study of organophosphorus poisoning at a rural-based teaching hospital in eastern Nepal. Trop Dr. 2001;31(1):32-4. https://doi. org/10.1177/004947550103100112.

27. Chakrabarti K, Devkota KC. Retrospective study of suicide cases admitted in Nepal medical college teaching hospital. Nepal Med Coll J. 2004;6(2):116-8.

28. Ghimire R, SP S, KR P. A Comparative Study of Changing Trends of Acute Poisoning Cases Admitted in the Internal Medicine Department of TUTH and Bharatpur District Hospital, between 1990-1992 and 2000-2002. J Nepal Health Res Counc. 2003.

29. Gupta S, Joshi M. Pesticide poisoning cases Attneding five major hospitals of Nepal. J Nepal Med Assoc. 2002;41:447-56.

30. Subba SH, Binu VS, Menezes RG, Kanchan T, Arun M, Patil R, et al. Pattern and trend of deliberate self-harm in western Nepal. J Forensic Sci. 2009; 54(3):704-7. https://doi.org/10.1111/j.1556-4029.2009.01040.x.

31. Khadka SB, Ale SB. A study of poisoning cases in emergency Kathmandu medical college teaching hospital. Kathmandu Univ Med J (KUMJ). 2005;3(4): 388-91.

32. Chhetri H, Khan G, Acharya A, Maharjan S, Manandhar M, Manandhar R, et al. ACUTE ORGANOPHOSPHATE POISONING: PATTERN, MANAGEMENT AND OUTCOMES. Pharmacologyonline; 2008.

33. Kishore PV, Palaian S, Paudel R, Mishra D, Ojha P, Alam K, et al. Pattern of poisoning cases in a teaching Hospital in Western Nepal. J Institute Med Nepal. 2008;30(1):26-34.

34. Paudyal BP. Poisoning : pattern and profile of admitted cases in a hospital in Central Nepal. JNMA J Nepal Med Assoc. 2005;44(159):92-6. 
35. Singh DP, Aacharya R. Pattern of poisonign cases in Bir hospital. J Institute Med Nepal. 2006;28(1):3-6.

36. Budhathoki S, Poudel P, Shah D, Bhatta NK, Dutta AK, Shah GS, et al. Clinical profile and outcome of children presenting with poisoning or intoxication: a hospital based study. Nepal Med Coll J. 2009;11(3):170-5.

37. Agrawaal KK, Karki P. Clinico-epidemiological study on pesticide poisoning in a tertiary care hospital in eastern Nepal. JNMA J Nepal Med Assoc. 2014; 52(196):972-6. https://doi.org/10.31729/jnma.2796.

38. Bhattarai N, Rauniyar A, Chaudhary D, Jaiswal S, Banthia P, Rana BB. Patterns of organophosphorous poisoning attending a teaching hospital. JNMA J Nepal Med Assoc. 2006;45(162):228-32.

39. Malla T, Malla KK, Rao KS, Gauchan E, S B, Koirala DP. A scenario of poisoning in children in Manipal teaching hospital. J Nepal Paediatr Soc. 2001;31(2):83-8.

40. Koirala D, Rao K, Malla K, Malla T. A study of Cliniocal features, management and outcome of Organophosphate and carbamate poisoning in children. J Nepal Paediatr Soc. 2013;33(2):85-90. https://doi.org/10.3126/jnps.v33i2.7799.

41. Pradhan SN, Adhikary SR. A study of severity of intention of suicide in various psychiatric diagnoses. Kathmandu Univ Med J. 2009;7(25):63-6.

42. Marahatta SB, Singh J, Shrestha R, Koju R. Poisoning cases attending emergency department in Dhulikhel Hospital- Kathmandu University Teaching Hospital. Kathmandu Univ Med J (KUMJ). 2009;7(26):152-6. https:// doi.org/10.3126/kumj.v7i2.2711.

43. Gurung CK, Dahal R, Khanal P, Nepal S, Jaiswal AK. Pattern of poisoning cases in a hospital in a Terai district of Central Nepal. Nepal Med Coll J. 2011;13(3):160-3.

44. Thapa SR, Lama P, Karki N, Khadka SB. Pattern of poisoning cases in emergency Department of Kathmandu Medical College Teaching Hospital. Kathmandu Univ Med J (KUMJ). 2008;6(2):209-13.

45. Chhetri UD, Ansari I, Shrestha S. Pattern of pediatric poisoning and accident in Patan hospital. Kathmandu Univ Med J (KUMJ). 2012;10(39):39-43. https:// doi.org/10.3126/kumj.v10i3.8016.

46. Maskey A, Parajuli M, Kohli SC, Baral S, Basnet S. N P: scenario of poisoning cases in adults admitted in Manipal teaching hospital, Pokhara, Nepal. Nepal J Med Sci. 2012;1(1):23-6.

47. Dhakal AK, Shrestha D, Shakya A, Shah SC, Shakya H. Clinical profile of acute poisoning in children at a teaching Hospital in Lalitpur. J Nepal Paediatr Soc. 2014:34(2):100-3. https://doi.org/10.3126/inps.v34i2.10139.

48. Lamsal D. Acute pesticide poisoning : review of PAtients attending at emergency Department in Chitwan Medical College. J Chitwan Med Col 2013;3(3):62-4. https://doi.org/10.3126/jcmc.v3i1.8469.

49. Baral B, Rajbhandari S, Shrestha A, Basnet B, Prasad PN. Acute poisoning cases in emergency Department of Tertiary Level Hospital, Kathmandu. J Gen Pract Emerg Med Nepal. 2011;2(3):54-8.

50. Karki RK, Risal A. Study of poisoning cases in a tertiary care hospital. Kathmandu Univ Med J (KUMJ). 2012;10(40):70-3. https://doi.org/10.3126/ kumj.v10i4.10999.

51. K.C S, Giri S, Gupta S, Pandey G. Scenario of Poisoning Cases in Devdaha Medical College Teaching Hospital, Pupandeni, Nepal: A Retrospective Study. Pharmaceutical Biosci J. 2020;8(3):01-4.

52. Bajracharya $M$, Khadka $P$, Wagle $L$. A retrospective study of poisoning cases in Manmohan memorial teaching hospital. J Manmohan Memorial Institute Health Sci. 2018;4(1):55-65. https://doi.org/10.3126/jmmihs.v4i1.21144.

53. Mandal L, Bhattarai MD, Gaire D, Koirala M, Bhattarai T, Adhikari S, et al. A study of organophosphorus poisoning at a tertiary care hospital in Nepal. Postgraduate Med J NAMS. 2013;13(1):31-3.

54. Rimal HS, Tiwari U, Ghimire K. M T: hospital based study of poisoning among children, 1 to 18 years of age in eastern Nepal. Birat J Health Sci. 2017;2(2):138-41. https://doi.org/10.3126/bjhs.v2i1.17293.

55. Shakya R, Adhikari S, Bajracharya R. Pattern of acute poisoning attending a tertiary Care Hospital of Western Nepal. J Lumbini Med Col. 2016;4(2):90. https://doi.org/10.22502/jlmc.v4i2.98.

56. Karki N, Singh V, Verma V. Pattern, management, and outcome of poisoning in a tertiary care hospital. J Lumbini Med Col. 2018;6(1):32-5.

57. Gaire D, Mandal L, Shrestha SL. Sociodemographic profile of organophosphorus poisoning case in a tertiary Care Hospital of Nepal. Post Graduate Med J Nat Acad Med Sci. 2015;16(01):19-23.

58. Gyenwali D, Vaidya A, Tiwari S, Khatiwada P, Lamsal D, Giri S. Pesticide poisoning in Chitwan, Nepal: a Descriptive Epidemiological Study. BMC Public Health. 2017:17:619.
59. Acharya K, Kandel IS, Gupta S, Poudel SD. A study on incidence and patterns of acute poisoning cases in an emergency Department of Western Region of Nepal. J Gandaki Med Col Nepal. 2019;12(2):59-62. https://doi. org/10.3126/jgmen.v12i2.27211.

60. Rajbanshi LK, Arjyal B, Mandal R. Clinical profile and outcome of patients with acute poisoning admitted in intensive care unit of tertiary Care Center in Eastern Nepal. Indian J Crit Care Med. 2018;22(10):691-6. https://doi.org/1 0.4103/ijccm.IJCCM_207_18.

61. Shrestha T, Aacharya R, Rp N. Predicting outcome of acute organophosphorus poisoning using poison severity score in patients presenting at a university hospital in Nepal. J Inst Med. 2018:40:17-21.

62. Chaudhary R, Rai B, Poudel M, Yadav A, Kafle N, Khadga SN, et al. Trend of poisoned patients' in emergency Department of a Tertiary Care Hospital of eastern Nepal. Int J Health Econ Policy. 2017;2:1-9.

63. Bhandari R, Bhandari R, Gupta PP: Trend and outcome of acute poisoning case: an experience from emergency department of eastern Nepal. 2017, 5(1):6.

64. Timsinha S, Rajesh S, Kar S. Sociodemographic characteristics and assessment of severity in organophosphorus poisoning in a tertiary care hospital. Int J Res Med Sci. 2017;5(9):3786-93. https://doi.org/10.18203/23206012.ijrms20173950.

65. Chataut J, Adhikari RK, Sinha NP, Marahatta SB. Pattern of organophosphorous poisoning: a retrospective community based study. Kathmandu Univ Med J (KUMJ). 2011;9(34):31-4. https://doi.org/10.3126/ kumj.v9i2.6284.

66. Jha S, Yadav BN, et al. Int J Ther Appl. 2014:17:10-5.

67. Yadav S, Yadav SP, Agrawal J, Shah G: Pattern of acute poisoning in children in a tertiary care hospital in eastern Nepal. 2016, 3(3):5.

68. Paudyal BP. Organophosphorus poisoning. JNMA J Nepal Med Assoc. 2008; 47(172):251-8

69. Thapaliya S, Sharma P, Upadhyaya K. Suicide and self harm in Nepal: a scoping review. Asian J Psychiatr. 2018;32:20-6. https://doi.org/10.1016/j.a jp.2017.11.018.

70. Rai BK. An epidemiological study of poisoning and Oitcome of treatment in emergency wards of a tertiary Care Hospital in Eastern Region of Nepal. Health Renaissance. 2010;7(1):43-6.

71. Kar SM, Timsinha S, Agrawal P. An epidemiological study of organophosphorus poisoning at Manipal Teaching Hospital, Pokhara, Nepal. J Indian Acad Forensic Med. 2010;32(2):108-9.

72. Rehiman S, Lohani SP, Bhattarai MC. Correlation of serum cholinesterase level, clinical score at presentation and severity of organophosphorous poisoning. JNMA J Nepal Med Assoc. 2008;47(170):47-52.

73. Mishra A, Shukla A, Yadav A, Gupta A. Epidemiological study of medicolegal organophosphorus poisoning in central region of Nepal. J Forensic Res. 2012;3:9.

74. Shrestha B, Singh PM, Bharati U, Dhungel S. Poisonings at Nepal medical college teaching hospital. Nepal Med Coll J. 2011;13(3):199-204.

75. Jacob KS. Suicide in India: part perceptions, partial insights, and inadequate solutions. The Nat Med J India. 2017;30(3):155-8.

76. Gunnell D, Eddleston M, Phillips MR, Konradsen F. The global distribution of fatal pesticide self-poisoning: systematic review. BMC Public Health. 2007; 7(1):357. https://doi.org/10.1186/1471-2458-7-357.

\section{Publisher's Note}

Springer Nature remains neutral with regard to jurisdictional claims in published maps and institutional affiliations.

Ready to submit your research? Choose BMC and benefit from:

- fast, convenient online submission

- thorough peer review by experienced researchers in your field

- rapid publication on acceptance

- support for research data, including large and complex data types

- gold Open Access which fosters wider collaboration and increased citations

- maximum visibility for your research: over $100 \mathrm{M}$ website views per year

At $\mathrm{BMC}$, research is always in progress.

Learn more biomedcentral.com/submission 